\title{
The milk requirements of the newborn calf
}

\author{
By J. H. B. ROY, K. W. G. SHILLAM, GILLIAN M. HAWKINS \\ AND JILL M. LANG \\ National Institute for Research in Dairying, Shinfield, near Reading
}

(Received 26 fune 1957-Revised 27 November 1957)

The relationship between milk intake and live-weight gain of the very young calf, when usually its sole diet is whole milk, has not been studied in the past in detail.

It is clear from our earlier experiments that, when calves are removed from their dams at birth, given not more than $6 \mathrm{pt}$. of colostrum and then bucket-fed, the growth curve during the first 3 weeks of life tends to be slightly curvilinear, even in the absence of scouring. This curvilinearity may be due partly to a subclinical disturbance in the alimentary tract, and partly to the high basal metabolic rate of the calf during the Ist week of life (Roy, Huffman \& Reineke, 1957). It possibly does not happen with calves that have suckled their dams and thus have taken larger quantities of colostrum (Walker, I950).

The Ragsdale (1934) growth standards are not available for a period shorter than the Ist month of life; for Holstein bull calves, a gain of $3 \mathrm{I} \mathrm{lb}$. from a birth weight of $94 \mathrm{lb}$. ( $\mathrm{I} \cdot 03 \mathrm{lb}$./day) is considered normal and for Ayrshire bull calves a gain of $20 \mathrm{lb}$. from a birth weight of $8 \mathrm{I} \mathrm{lb} .(0.67 \mathrm{lb}$. day $)$. In view of the slight curvilinearity of the growth curve during the first ro days, these values would be somewhat lower for the first 3 weeks of life. Woodman (I948) suggests that calves require about I gal. milk daily during the first 2 weeks of life, but he gives no details of growth rate, other than that a gain of 8-9 lb. a week can be expected before weaning. Another commonly accepted standard of milk requirement for normal live-weight gain is I lb. milk/1o lb. live weight.

Until fairly recently there was little knowledge of the basal metabolism of the young calf or of its efficiency in the utilization of milk. Blackwood, Morris \& Wright (1936) found that the apparent digestibility of nitrogen and phosphorus in milk-fed calves was about $94 \%$. Tomme \& Taranenko (1939), using calves of 25 days of age and over, showed that the net energy of whole milk was $68.5 \%$ of the gross energy, and that the apparent digestible energy was $95 \cdot 1 \%$ of the gross energy. The mean basal metabolism of their calves was $5^{\mathrm{I}} \mathrm{Cal} . \mathrm{kg} / 24 \mathrm{~h}$. Under commercial farm conditions Brody, Kibler \& Ragsdale (I94I, I942) found resting-metabolism values for Holstein calves of $4^{6.9} \mathrm{Cal} . / \mathrm{kg} / 24 \mathrm{~h}$ at $\mathrm{I} 2$ days of age and for Jersey calves weighing $25 \mathrm{~kg}$ a value of 52. I Cal. $/ \mathrm{kg} / 24$ h. Blaxter $\&$ Wood (I95 I $a$ ), using synthetic-milk diets, showed that the basal energy metabolism of Ayrshire calves at about $\mathrm{I}$ month of age was $43 \cdot$ I Cal. $/ \mathrm{kg} / 24 \mathrm{~h}$.

In further experiments Blaxter $\&$ Wood $(195 \mathrm{I} b)$ established a relationship between the intake of apparently digested energy and gain in body-weight from which they 
deduced that the digestible energy required for body-weight maintenance for a calf weighing about $34 \mathrm{~kg}$ was $177 \mathrm{I}$ Cal./day and that each gain of $100 \mathrm{~g}$ body-weight was associated with an intake of an additional $307 \mathrm{Cal}$. The maintenance requirement was thus $52.4 \mathrm{Cal}$. digested energy $/ \mathrm{kg} /$ day which, allowing for an activity increment of $25-30 \%$, was in conformity with their earlier finding of $43.1 \mathrm{Cal} . / \mathrm{kg} / \mathrm{day}$ for basal energy requirement (Blaxter \& Wood, I95 I $a$ ). From N-balance experiments, they established a relationship between $\mathrm{N}$ balance and gain in weight, and from their finding that the endogenous $\mathrm{N}$ metabolism of the calf was $80 \mathrm{mg} / \mathrm{kg}$ body-weight (Blaxter \& Wood, I95 I $a$ ) they were able to calculate the digestible energy required in Cal./day, and the percentage of the digestible energy needed as protein to avoid energy being obtained from protein deamination. For maintenance of body-weight of a $30 \mathrm{~kg}$ calf $\mathrm{I}_{572} \mathrm{Cal}$./day of digestible energy was required with $6.9 \%$ of this energy present as protein.

In another experiment Blaxter \& Wood ( $1952 a$ ) related body-weight gain to quantity of whole milk $(3 \cdot 0-3 \cdot 1 \%$ fat $)$ ingested during the period $5-41$ days of age. For two Ayrshire calves, they calculated the mean milk intake for no change in body-weight as $2 \cdot 65 \pm 0.161$. d day. The apparent digestibility of $\mathrm{N}$ was $93.8 \%$ and of fat $95.6 \%$, the values being in agreement with those of Blackwood et al. (1936) and Tomme \& Taranenko (I939). From the results of Blaxter \& Wood, it was clear that body-weight maintenance in the young calf involved storage of minerals in the bone and deposition of protein. We have found similar results with the young calf maintained at its birth weight for several months (Roy, Shillam \& Hawkins, 1956).

In a further experiment, Blaxter (I952) determined the net-energy value of milk by measuring the increase in heat production and energy balance that occurs after an increase in food intake. He found that the net availability of metabolizable energy was $85 \%$ and that the maintenance requirement was $\mathrm{I} 20 \mathrm{Cal}$. of net energy or I $40 \mathrm{Cal}$. of metabolizable energy $/ \mathrm{kg}$ metabolic body size (Brody, 1945). For a calf weighing $35 \mathrm{~kg}$ this was equivalent to $1608 \mathrm{Cal}$. of net energy or $1876 \mathrm{Cal}$. of metabolizable energy/ $24 \mathrm{~h}$. These values may be compared with those obtained from regression of bodyweight gain on digestible-energy intake, $177 \mathrm{I} \pm 97 \mathrm{Cal}$. digested energy/24 $\mathrm{h}$ (Blaxter \& Wood, 195 $1 b$ ) and $1921 \pm 129$ Cal. (Blaxter \& Wood, $195^{2} b$ ). In the experiment of Blaxter (1952), the total energy ingested was metabolized to the extent of $94 \%$ at the lower level of feeding and $97 \%$ at the higher.

Further values for basal metabolic rate were found by Blaxter $\&$ Wood $\left(195^{2} b\right)$ in an experiment in which gelatin and casein were compared as sources of amino-acids in the young ruminant calf, namely 46.5 and $44.5 \mathrm{Cal} / \mathrm{kg} / 24 \mathrm{~h}$ for 4.81 . and 4.41 . daily of the diet, respectively, compared with the earlier value of $43^{\cdot} \mathrm{I} \mathrm{Cal} \cdot / \mathrm{kg} / 24 \mathrm{~h}$ (Blaxter \& Wood, 1951 $a$ ). Roy et al. (1957) studied the change in basal metabolic rate during the first 3 weeks of life, and obtained average values of ${ }_{5} \mathrm{I} \mathrm{Cal./} / \mathrm{kg} / 24 \mathrm{~h}$ at 2 days of age falling to $32 \mathrm{Cal} / \mathrm{kg} / 24 \mathrm{~h}$ at 21 days.

In the course of experiments made by us during the last 8 years, a large amount of information has been accumulated on the relationship between milk intake and gain in body-weight. In most of the experiments the calves were fed at the rate of $\mathrm{I} \mathrm{lb}$. milk/ ro lb. live weight, but the quantity was reduced when alimentary disorders 
occurred. Significant partial regression coefficients of live-weight gain on birth weight and on milk consumption have been found in all experiments, thus indicating that statistical adjustment of weight gains for between-treatment differences in birth weight and milk consumption is necessary when calves are given milk at the rate of $\mathrm{I} l \mathrm{~b}$. milk/ro lb. live weight. The variance of live-weight gain/day before regression analysis has been of the order of $0 . \mathrm{I} \mathrm{lb}$./day, whereas after analysis the value has been reduced to about $0.015 \mathrm{lb}$./day. By calculation of the requirements of milk for maintenance and body-weight gain, not only could a new feeding standard be adopted that had a rational basis, but also the findings could be compared with those of other workers, particularly Blaxter and his colleagues.

Our findings are reported in four sections: Part I deals with the statistical calculation of the requirements for 'synthetic milk', Part 2 with a feeding trial to test these standards and Part 3 with a similar trial in which whole milk was the diet; as the results for 'synthetic milk' and whole milk differed, the statistical calculation of the requirements for whole milk is presented in Part 4 .

PART I. CALCULATION OF THE REQUIREMENT OF THE CALF

IN TERMS OF A 'SYNTHETIC MILK'

\section{Experimental}

A total of 122 Shorthorn bull calves in five experiments was used for this study. The majority received the 'synthetic milk' of the following constant composition (Aschaffenburg, Bartlett, Kon, Terry, Thompson, Walker, Briggs, Cotchin \& Lovell, I949):

$\begin{array}{lllr}\text { Spray-dried skim milk } & 9.8 \% & \text { Water } & 85.7 \% \\ \text { Non-vitaminized margarine } & 2.0 \% & \text { Vitamin A } & 3500 \text { i.u. daily } \\ \text { Glucose } & 2.5 \% & \text { Vitamin D } & 700 \text { i.u. daily }\end{array}$

There were some exceptions, but it was considered that such variations in composition of diet were so slight that the results would not be affected, especially as the total number of calves used was large.

In three of the experiments no calf received more than 6 pt. (3410 ml.) of colostrum and the majority were given $400 \mathrm{ml}$, whereas in the remaining two experiments, calves in two treatments received colostrum for longer periods.

Multiple covariance analyses of mean live-weight gain/day, obtained by fitting a linear regression to the twenty-one daily weights $\left(y_{1}\right)$, and also from the difference between the 2 Ist-day weight and the Ist-day weight divided by $20\left(y_{2}\right)$, were made for all the experiments. The affecting variables were:

$x_{1}=$ birth weight (lb.)

$x_{2}=$ total milk consumption in $2 \mathrm{I}$ days (pt.)

$x_{3}=$ no. of days on which a calf scoured

$\left.\begin{array}{c}x_{3}=\text { no. of days on which a calf scoured } \\ x_{4}=\text { no. of days on which rectal temperature was } \\ \text { greater than IO2.8 } 8^{\circ} \mathrm{F} \text {. }\end{array}\right\} \begin{aligned} & \text { Values for } x_{3} \text { and } x_{4} \text { transformed } \\ & \text { thus: } \sqrt{ }\left(x+\frac{1}{2}\right)\end{aligned}$

$x_{5}=$ 'occupation time' (log days).

'Occupation time' is defined by Roy, Palmer, Shillam, Ingram \& Wood (1955) as the 
number of days that the calfhouse had been occupied after a period of vacancy. That part of the residual error due to differences between treatments within each experiment was removed before analysis, as was that part of the error due to differences between blocks in two of the experiments. In the remaining experiments the arrangement in blocks was ignored.

\section{Results}

For each experiment, partial regression coefficients of mean live-weight gain/day $\left(y_{1}\right.$ and $\left.y_{2}\right)$ on the above-mentioned variates were calculated. In all experiments certain partial regression coefficients, such as live-weight gain on the incidence of scouring, were not significant. The regressions were, therefore, recalculated with the non-significant variates omitted. The final regression equations in relation to $y_{2}$ are given below; those in relation to $y_{1}$ were in general very similar and are not presented owing to limitations of space.

Exp. I: $\quad Y_{2}=0.434-0.0165\left(x_{1}-76.73\right)+0.0152\left(x_{2}-\right.$ I 10.49)-0.1 I $78\left(x_{4}-\right.$ I.306),

$$
\text { S.E. }=0 \cdot 1 \mathrm{I} 8 \text {; }
$$

Exp. 2: $\quad Y_{2}=0.200-0.0124\left(x_{1}-85.50\right)+0.0144\left(x_{2}-102 \cdot 79\right)$, S.E. $=0.107$;

Exp. 3: $\quad Y_{2}=0.596-0.0140\left(x_{1}-79.65\right)+0.0141\left(x_{2}-124.68\right)$, s.E. $=0.084$;

Exp. 4: $\quad Y_{2}=0.652-0.0175\left(x_{1}-84.17\right)+0.0159\left(x_{2}-\right.$ I33.07), S.E. $=0.128$;

Exp. 5: $\quad Y_{2}=0.058-0.0196\left(x_{1}-79.0\right.$ I $)+0.0183\left(x_{2}-\right.$ IOI.99), S.E. $=0$. I 84 .

The symbols are explained on p. 125 .

Table 1. Part 1. 'Synthetic milk' requirements for various live-weight gains of calves of different birth weights, calculated by means of variable $Y_{2}$ (see p. 125)

\section{Live-weight
gain/day}

(lb.)

$\circ$

3
4
5
Weighted mean
Gross energy

0.5

$\begin{array}{cc}\text { I } & 32 \\ 2 & 22 \\ 3 & 22 \\ 4 & 26 \\ 5 & 18 \\ \text { Weighted mean } & \end{array}$

$1 \cdot 0$
(Cal.)

Gross energy

(Cal.)

No. of calves

32

22

24

26

18

32
22
24
26
18

32
22
24
26
18

Weighted mean

Gross energy

(Cal.)
Milk requirement (pt./day) of calf of birth weight

\begin{tabular}{|c|c|c|}
\hline $60 \mathrm{lb}$. & $80 \mathrm{lb}$. & $100 \mathrm{lb}$ \\
\hline $2 \cdot 81$ & $3 \cdot 84$ & $4 \cdot 88$ \\
\hline $3 \cdot 19$ & 4.01 & $4 \cdot 83$ \\
\hline $2 \cdot 99$ & $3 \cdot 94$ & $4 \cdot 89$ \\
\hline $3 \cdot 13$ & $4 \cdot 17$ & 5.22 \\
\hline 3.73 & $4 \div 75$ & $5 \cdot 78$ \\
\hline $\begin{array}{l}3 \cdot 12(x \cdot 771 .) \\
1257\end{array}$ & $\begin{array}{l}4.09(2 \cdot 321 .) \\
1648\end{array}$ & $\begin{array}{l}5.08(2.891 .) \\
2047\end{array}$ \\
\hline $\begin{array}{l}4 \cdot 38 \\
4 \cdot 84 \\
4 \cdot 68 \\
4 \cdot 62 \\
5 \cdot 04\end{array}$ & $\begin{array}{l}5 \cdot 42 \\
5 \cdot 66 \\
5 \cdot 63 \\
5 \cdot 66 \\
6 \cdot 06\end{array}$ & $\begin{array}{l}6 \cdot 45 \\
6 \cdot 48 \\
6 \cdot 58 \\
6 \cdot 71 \\
7.08\end{array}$ \\
\hline $\begin{array}{l}4 \cdot 67(2 \cdot 651 .) \\
1882\end{array}$ & $\begin{array}{l}5 \cdot 65(3 \cdot 2 \text { I } 1 .) \\
2277\end{array}$ & $\begin{array}{l}6 \cdot 63(3.771 .) \\
2672\end{array}$ \\
\hline $\begin{array}{l}5 \cdot 95 \\
6 \cdot 50 \\
6 \cdot 37 \\
6 \cdot 12 \\
6 \cdot 34\end{array}$ & $\begin{array}{l}6 \cdot 99 \\
7 \cdot 32 \\
7 \cdot 32 \\
7 \cdot 16 \\
7 \cdot 36\end{array}$ & $\begin{array}{l}8 \cdot 03 \\
8 \cdot 14 \\
8 \cdot 27 \\
8 \cdot 20 \\
8 \cdot 38\end{array}$ \\
\hline $\begin{array}{l}6 \cdot 23(3.541 .) \\
25 \text { II }\end{array}$ & $\begin{array}{l}7 \cdot 21(4 \cdot 101 .) \\
2906\end{array}$ & $\begin{array}{l}8 \cdot 18(4 \cdot 651 .) \\
3297\end{array}$ \\
\hline
\end{tabular}


From these equations, the milk consumption in pt./day was calculated for liveweight gains of $0,0.5$ and $\mathrm{r} \cdot 0 \mathrm{lb}$./day for calves of 60,80 and $100 \mathrm{lb}$. birth weight. For the variate, the incidence of a high rectal temperature $\left(x_{4}\right)$ included in the equation of Exp. I, a value for zero incidence of a high rectal temperature was substituted in the equation.

The calculated daily milk requirements for various live-weight gains for each of the five experiments together with the weighted means are given in Table I and, graphically, with curves of standard deviation of calculated live-weight gain in Fig. I.

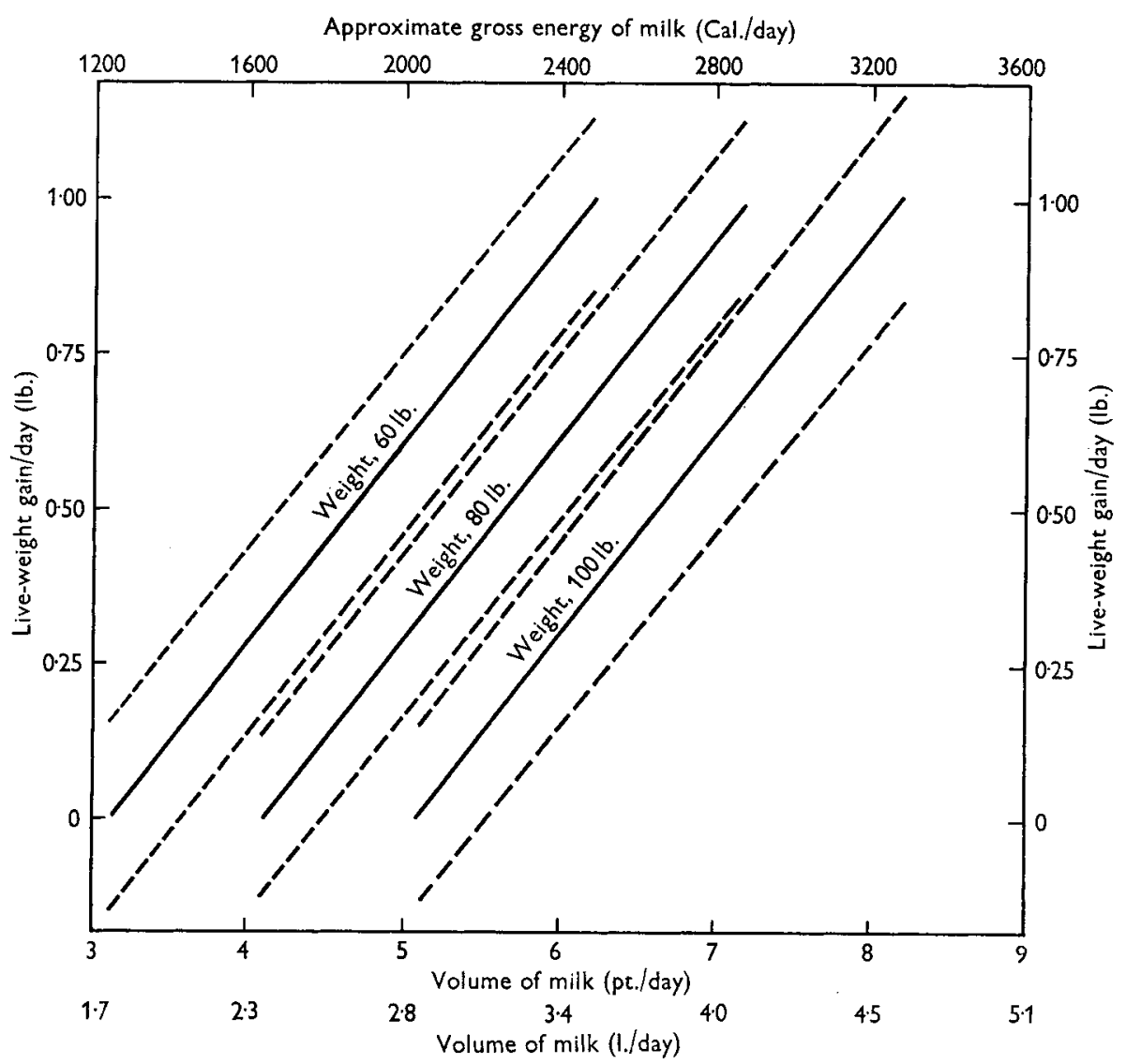

Fig. I. 'Synthetic milk' requirements of the young calf during the first 3 weeks of life. — , regression lines; - - - , standard-deviation curves of daily live-weight gain.

The milk requirement for a given weight change was slightly greater when mean live-weight gain was calculated from the difference between weight at birth and on the 21st day $\left(y_{2}\right)$ than when obtained from the linear regression on twenty-one daily weights $\left(y_{1}\right)$. It would seem probable that the most accurate value is the mean of the two estimations, for $y_{1}$ has the disadvantage of overestimating live-weight gain owing to the slight curvilinearity of the regression during the ist week of life but has the advantage of being based on twenty-one daily weights, whereas $y_{2}$ gives a truer 
picture of actual weight gain but has the disadvantage of being based on only two weighings. However, only the results obtained by the use of $y_{2}$ are given. The grossenergy value of the milk, which is also given in the table, was calculated from analytical values by means of the factors which Blaxter (r952) adopted from Andersen (1926), namely $9.1 \mathrm{I}$ Cal./g for fat, $5.86 \mathrm{Cal} . / \mathrm{g}$ for protein and $3.95 \mathrm{Cal} . / \mathrm{g}$ for lactose and glucose. The percentage composition of the spray-dried skim milk was as follows: protein $35^{\circ}$, lactose $50 \cdot 8$, ash $7 \cdot 7$, fat 0.7 and moisture 5.4 . These values are in close agreement with those of Hunziker (1949), obtained from the analysis of 291 samples in America. Thus, I pt. of the 'synthetic milk' had an energy value of 403 Cal., with $29.6 \%$ of the total calories present as protein.

From Table $\mathrm{I}$, it can be seen that, for every lb. of gain in weight, it was necessary for the calves to ingest $1254 \mathrm{Cal}$. above their maintenance requirement. On conversion, this value is $276 \mathrm{Cal}$. of ingested energy/100 g gain in body-weight compared with the value of $307 \mathrm{Cal}$. of digested energy/100 g gain found by Blaxter \& Wood ( $195 \mathrm{I} b$ ).

PART 2. EXP. A. PERFORMANCE OF CALVES GIVEN QUANTITIES OF 'SYNTHETIC MILK' CALCULATED TO GIVE VARIOUS CHANGES IN BODY-WEIGHT

To verify that the calculated quantities of milk required for maintenance and liveweight gain for various birth weights were in agreement with those determined experimentally on calves given these quantities of milk, a feeding trial was planned.

\section{Plan of experiment}

\section{Methods}

The experiment was done in the autumn of $195^{2}$ after the calfhouse had been empty for $4 \frac{1}{2}$ months. There were four treatments in each of eight blocks of Shorthorn bull calves as follows:

Treatment no.

$\left.\begin{array}{l}\text { I } \\ 2 \\ 3 \\ 4\end{array}\right\}$

Diet

6 pt. whole
colostrum

Diets

Colostrum. Twenty-three batches of colostrum, obtained within $24 \mathrm{~h}$ of calving, from Shorthorn cows were used: I pt. samples were stored separately at $-25^{\circ}$. Each calf was given 6 pt. of colostrum consisting of I pt. from each of six batches of colostrum. Calves in any one block received the same colostrum, but there were occasional differences between the blocks.

'Synthetic milk' (see p. I25). 'The quantity of 'synthetic milk' given each day was calculated according to treatment and birth weight of the calf by interpolation of the values shown in Fig. I, adjustments being made when appropriate by steps of $\frac{1}{2} \mathrm{pt}$.

\section{Calves}

The calves, whose birth weight ranged from 60 to $108 \mathrm{lb}$., were managed as in earlier experiments (Aschaffenburg, Bartlett, Kon, Roy, Walker, Briggs \& Lovell, 
I95 I). If a calf in treatment I scoured no adjustment was made to the milk intake, but in treatments $2-4$ the quantity of milk was reduced and the method described by Aschaffenburg et al. ( 95 I) adopted.

\section{Results}

The results are given in Table 2. Two calves that received milk at the highest level of intake on treatments 3 and 4 of block 8 died and showed at post-mortem an Escherichia coli localized intestinal infection.

Table 2. Part 2. Performance of calves given quantities of 'synthetic milk' calculated by means of $Y_{2}$ (see p. 125) to give various changes in live weight

No. of calves

Mean birth weight (lb.)

Mean no. of days on which scouring occurred

Mean live-weight gain/day (lb.)

Adjusted mean live-weight gain/day (Ib.) $f$

Mean live-weight gain/day of first

three blocks (lb.)

Mean daily rectal temperature during

first 3 weeks of life ( ${ }^{\circ} \mathrm{F}$.)
Treatment no.

\begin{tabular}{|c|c|c|c|}
\hline \multicolumn{3}{|c|}{$\stackrel{2}{\text { Intended performance }}$} & \multirow{2}{*}{$\begin{array}{c}4 \\
\text { I lb. } \\
\text { milk/ } 10 \mathrm{lb} . \\
\text { live weight }\end{array}$} \\
\hline Maintenance & $\frac{1}{2}$ lb. gain/day & I lb. gain/day & \\
\hline $\begin{array}{c}8 \\
86 \cdot 0\end{array}$ & $\begin{array}{c}8 \\
86 \cdot 1\end{array}$ & $\begin{array}{c}8 \dagger \\
82 \cdot 7\end{array}$ & $\begin{array}{r}8 \dagger \\
87 \cdot 6\end{array}$ \\
\hline $3 \cdot I$ & $3 \cdot 6$ & $3 \cdot 6$ & $5 \cdot 3$ \\
\hline $\begin{array}{r}-0.08 \pm 0.04 \\
0.04 \pm 0.05\end{array}$ & $\begin{array}{l}0.14 \pm 0.14 \\
0.61 \pm 0.21\end{array}$ & $\begin{array}{l}0.57 \pm 0.12 \\
1.00 \pm 0.26\end{array}$ & $\begin{array}{l}0.27 \pm 0.12 \\
0.69 \pm 0.11\end{array}$ \\
\hline$-0.02 \pm 0.03$ & $0.49 \pm 0.09$ & $0.89 \pm 0.05$ & $0.5^{8} \pm 0.02$ \\
\hline $\mathrm{IOI} \cdot 5 \pm 0.12$ & $101 \cdot 8 \pm 0.12$ & $102 \cdot 0 \pm 0.13$ & $102 \cdot 0 \pm 0.13$ \\
\hline
\end{tabular}

Significance of difference between mean daily rectal temperatures: treatment $I<$ treatment $3^{* *}$; treatment $2<$ treatment $4^{* *}$.

** Significant at $P<0.01$. $\dagger$ One calf died in this treatment. $\ddagger$ Adjusted for 'occupation time'.

Unfortunately, the build-up of 'infection' with 'occupation time' (Roy, Palmer et al. 1955) caused calves to grow subnormally in blocks subsequent to the third. The mean values for all eight blocks were therefore below the expected values, the difference being smallest with calves on the maintenance treatment. If the first three blocks only are considered the mean values are very close to the expected values.

Calculated regression coefficients of live-weight gain (lb./day) on scouring and on 'occupation time' were:

\begin{tabular}{|c|c|c|c|c|}
\hline \multirow{2}{*}{$\begin{array}{l}\text { Regression } \\
\text { coefficient }\end{array}$} & \multicolumn{4}{|c|}{ Value of coefficient for treatment no. } \\
\hline & $\mathbf{I}$ & 2 & 3 & 4 \\
\hline $\begin{array}{l}b y_{2} \sqrt{\left(x+\frac{1}{2}\right)} \\
b y_{2} t\end{array}$ & $\begin{array}{l}-0.004 \pm 0.066 \\
-0.004 \pm 0.00 I^{*}\end{array}$ & $\begin{array}{l}-0.428 \pm 0.067^{* * *} \\
-0.015 \pm 0.006^{*}\end{array}$ & $\begin{array}{l}-0.507 \pm 0.085^{* *} \\
-0.016 \pm 0.008\end{array}$ & $\begin{array}{l}-0.416 \pm 0.106^{*} \\
-0.016 \pm 0.004^{* *}\end{array}$ \\
\hline
\end{tabular}

It is apparent that scouring did not affect live-weight gain in treatment $I$ and that in general the effect of scouring on live-weight gain increased with increasing quantities of milk in treatments 2-4. Moreover, although 'occupation time' affected live-weight 
gain in all treat ments, there was an indication that its effect was greatest at levels of feeding above maintenance. Each treatment mean was adjusted individually, the regression coefficient of live-weight gain on 'occupation time' being used to give a value that would have been expected if live-weight gain had not decreased with increasing 'occupation time'. As live-weight gain was related to 'occupation time' more closely than to $\log$ 'occupation time', the former was used in the calculation of the regression coefficients. The regression coefficients of live-weight gain on scouring were not used since adjustment for a high incidence of scouring, when transformed, tends to give abnormally high values of live-weight gain at zero incidence of scouring. The adjusted mean values are given in Table 2 and are similar to the expected mean values and to the means for the first three blocks. However, the standard errors of these adjusted means of treatments $2-4$ are large.

The mean daily rectal temperature of calves given the maintenance ration was significantly lower than that of calves given the larger volumes of milk on treatments 3 and 4 .

\section{Discussion}

The results of this experiment, although not conclusive owing to the build-up of 'infection', suggest that the 'synthetic milk' requirements calculated from multiple regression analyses are in fact borne out by direct experiment. In particular, there is little doubt that the maintenance requirement for various birth weights is correct, for scouring had no effect on growth rate in this treatment and the adjustment for 'occupation time' was small.

The 'synthetic milk' requirement, although in general agreement with the values obtained by Blaxter \& Wood (195 I $b$ ), is nevertheless somewhat lower. This difference may be due in part to the ingestion by the calves of wheat straw used for bedding in our experiments, although in one experiment the mean dry-matter content of the reticulo-rumens of twenty-four calves at 21 days of age was only $43 \mathrm{~g}$; straw ingestion would thus increase the gain in body-weight slightly although having a negligible nutritive effect. It is unlikely that the discrepancy is associated with breed difference for, although Blaxter and his colleagues used Ayrshire calves in their experiments whereas the regression equations for live-weight gain of calves given 'synthetic milk' were calculated from data for Shorthorn calves, we have been unable to demonstrate any difference in growth rate of calves of these two breeds when given the same quantities of whole milk (e.g. Roy, Shillam, Palmer \& Ingram, 1955).

The increasing size of the regression coefficients of live-weight gain on 'occupation time' and the tendency for a higher incidence of scouring in calves given the larger amounts of milk, suggest that the quantity of readily fermentable liquid in the alimentary tract of the calf affects not only the incidence of scouring in calves but also the rate at which the incidence of scouring increases with 'occupation time'. 
PART 3. EXP. B. PERFORMANCE OF CALVES GIVEN QUANTITIES OF WHOLE MILK CALCULATED TO GIVE VARIOUS CHANGES IN BODY-WEIGHT

Having established feeding standards for 'synthetic milk' as the diet, we thought it desirable to repeat the experiment with whole milk.

\section{Plan of experiment}

\section{Methods}

The experiment was done in the autumn of 1953 after the calfhouse had been empty for 4 months, with four treatments in each of twelve blocks of Shorthorn bull calves. The layout was as follows:

Treatment no.

$\left.\begin{array}{l}5 \\ 6 \\ 7 \\ 8\end{array}\right\}$

6 pt. whole colostrum
Diet

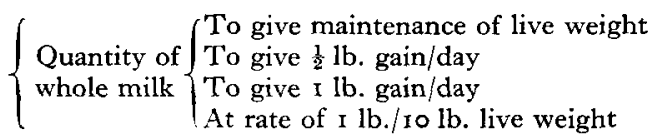

Diets

Colostrum. The collection of colostrum and method of feeding were as for Exp. A.

Whole milk. Since the calorific value of whole milk was known to be very similar to that of 'synthetic milk' the same quantity was fed to the calves as on the corresponding treatments in Exp. A. The weighted mean composition of the whole milk used throughout the experiment was $3.32 \%$ fat and $8.77 \%$ solids-not-fat. By applying the factors of Andersen (1926), the gross energy value was determined as $398 \mathrm{Cal} . / \mathrm{pt}$. with $29.3 \%$ of the total calories present as protein, compared with $403 \mathrm{Cal} . / \mathrm{pt}$. and $2.6 \%$ of the total calories present as protein for the "synthetic milk'.

\section{Calves}

The calves, whose birth weight ranged from 62 to I Io lb., were managed as in Exp. A except when scouring occurred. In Exp. A scouring had little effect on growth rate of calves that were given milk at a level for maintenance of body-weight, and therefore in Exp. B one feed was omitted at the onset of scouring and a maintenance ration was then given to calves in treatments $6-8$ until faeces were of normal consistency.

\section{Results and discussion}

From the results given in Table 3 it appeared that the value of whole milk for maintenance of body-weight was very similar to that of 'synthetic milk'. As 'occupation time' did not significantly affect live-weight gains, the means for treatments $6-8$ were adjusted for the incidence of scouring by means of the following regression coefficients:

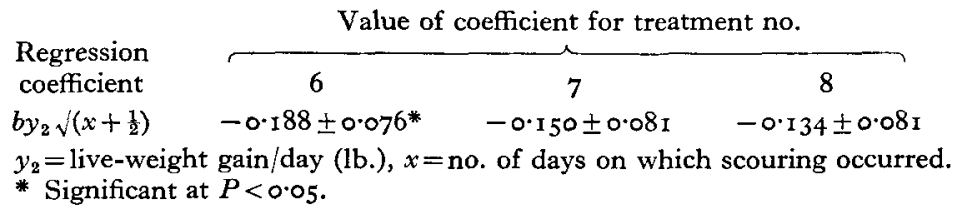


After adjustment for scouring, the means of treatments 6 and 7 , given in Table 3, were lower by about $\mathrm{I} 5^{-20} \%$ than the expected values of 0.5 and $\mathrm{I} \cdot 0 \mathrm{lb}$./day, and thus were also lower than the gains obtained with equal volumes of 'synthetic milk', even though the calorific values of the two diets were the same.

As in Exp. A, the mean daily rectal temperature was lower for calves given the maintenance ration than for calves on the other three treatments. In addition, calves expected to gain $0.5 \mathrm{lb}$./day had lower rectal temperature than those given milk at the rate of $\mathrm{I} \mathrm{lb}$./ $10 \mathrm{lb}$. live weight.

Table 3. Part 3. Performance of calves given quantities of whole milk calculated by means of $Y_{2}$ (see p. 125) to give various changes in live weight

Treatment no.

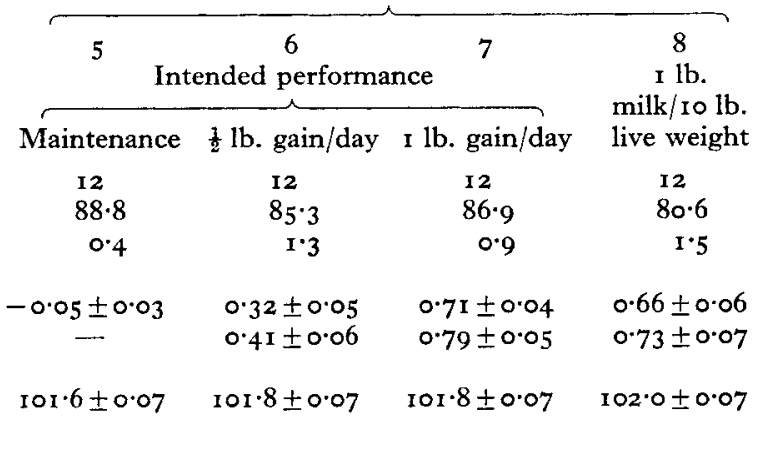

No. of calves

Mean birth weight (lb.)

Mean no. of days on which scouring occurred

Mean live-weight gain/day (lb.)

Adjusted mean live-weight gain/day

(lb.) $\dagger$

Mean daily rectal temperature during

first 3 weeks of life $\left({ }^{\circ} \mathrm{F}\right.$.)

Significance of difference between mean daily rectal temperatures: treatment $5<$ treatment $6^{*}$; treatment $5<$ treatment $7^{* *}$; treatment $5<$ treatment $8^{* * *}$; treatment $6<$ treatment $8^{*}$.

* Significant at $P<0.05$. ** Significant at $P<0.01$. *** Significant at $P<0.001$. $\dagger$ Adjusted for incidence of scouring.

\section{PART 4. CALCULATION OF THE REQUIREMENT OF THE CALF IN TERMS OF WHOLE MILK}

Since Exp. B was done, more information has accumulated on the relationship between whole-milk intake and weight gain, and it has, therefore, been possible to calculate the whole-milk requirements in a manner similar to that adopted for the 'synthetic milk'.

\section{Results}

Multiple covariance analyses of live-weight gain/day of I Io Shorthorn and 92 Ayrshire calves grouped in seven experiments and given not more than $6 \mathrm{pt}$. of colostrum have been made with the use of the variables stated earlier in this paper. The final regression equations after omission of the non-significant variates are given below:

Exp. 6: $\quad Y_{2}=0.595-0.0170\left(x_{1}-81 \cdot 26\right)+0.0166\left(x_{2}-132.59\right)$, S.E. $=0$. I I 8 ;

Exp. 7: $\quad Y_{2}=0.391-0.0190\left(x_{1}-74.97\right)+0.0178\left(x_{2}-116.92\right)$, S.E. $=0.105$;

Exp. 8: $\quad Y_{2}=0.394-0.0158\left(x_{1}-83.69\right)+0.0150\left(x_{2}-131 \cdot 68\right)$, S.E. $=0.123$;

Exp. 9: $\quad Y_{2}=0.231-0.0214\left(x_{1}-85.52\right)+0.0171\left(x_{2}-126.96\right)-1.075\left(x_{5}-2.338\right)$,

$$
\text { S.E. }=0 \cdot 088
$$


Exp. 10: $Y_{2}=0.29 \mathrm{I}-0.025 \mathrm{I}\left(x_{1}-8 \mathrm{I} \cdot 70\right)+0.023 \mathrm{I}\left(x_{2}-\mathrm{I} 2 \mathrm{I} \cdot 04\right)$, S.E. $=0.136$;

Exp. II: $Y_{2}=0.176-0.0193\left(x_{1}-77.02\right)+0.0192\left(x_{2}-114.11\right)$, S.E. $=0.112$;

Exp. 12: $Y_{2}=0.478-0.0215\left(x_{1}-78.82\right)+0.0179\left(x_{2}-122 \cdot 20\right)$, S.E. $=0.115$.

The symbols are explained on p. 125 .

From these equations, the whole-milk consumption in pt./day necessary for liveweight gains of $0,0.5$ and $\mathrm{I} \cdot 0 \mathrm{lb}$./day for calves of 60,80 and $100 \mathrm{lb}$. birth weight was calculated. For the variate 'occupation time' $\left(x_{5}\right)$ included in the equation of Exp. 9 , a value for the day that the experiment began was substituted in the equation.

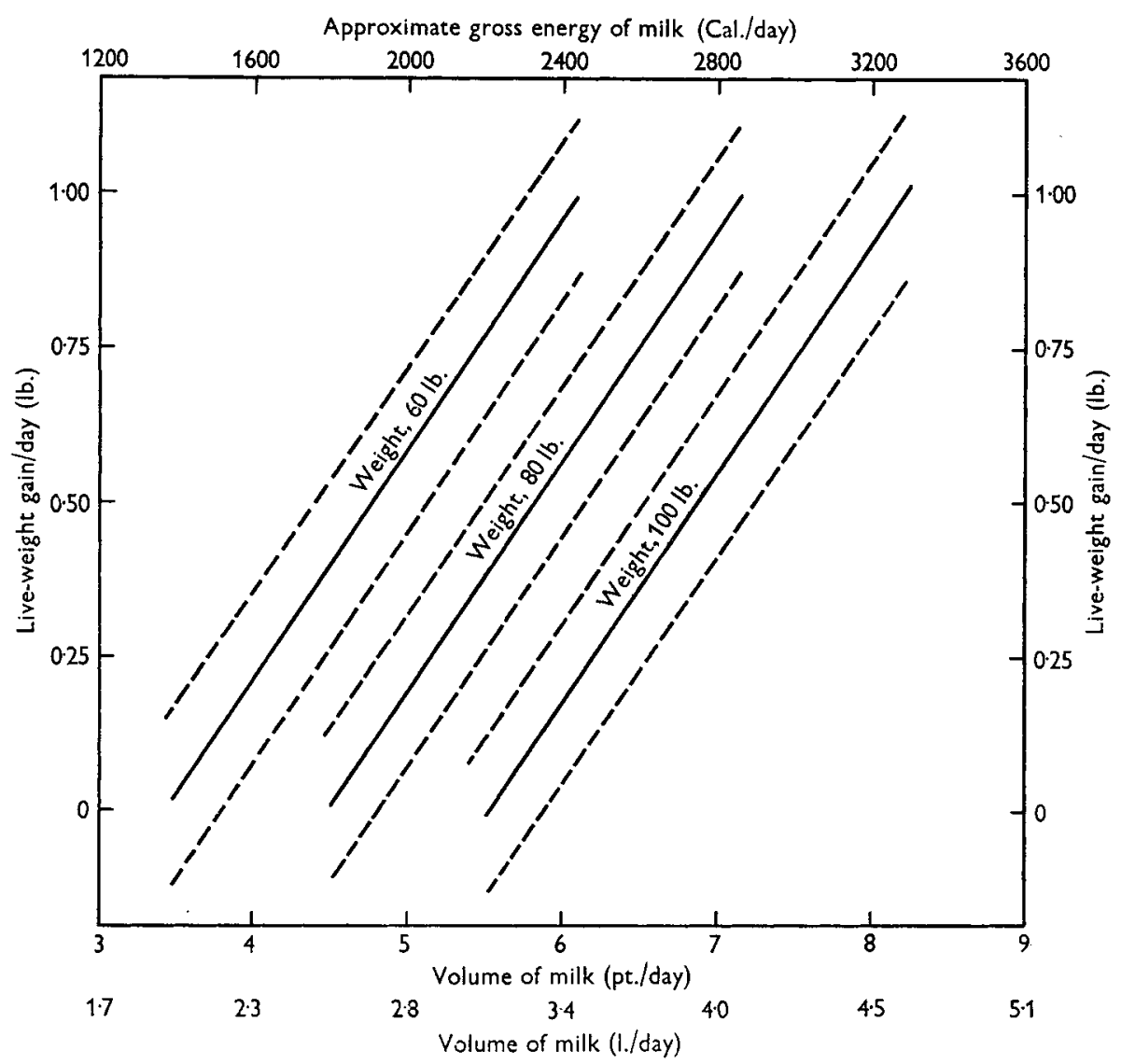

Fig. 2. Whole-milk requirements of the young calf during the first 3 weeks of life. _- regression lines; - - - , standard deviation curves of daily live-weight gain.

The daily whole-milk requirements calculated from the seven equations are given in Table 4 and the mean values together with the standard deviation curves are presented graphically in Fig. 2. The gross-energy value of the whole milk used in these seven experiments was calculated from compositional data, mean average values of $3.32 \%$ fat and $8.77 \%$ solids-not-fat being taken.

It can be seen from Table 4 that for $\mathrm{I}$ lb. gain in weight, it was necessary for the calves to ingest $1068 \mathrm{Cal}$. above their maintenance requirement ( $235 \mathrm{Cal} / / \mathrm{roO} \mathrm{g}$ gain), 
a value not very different from that obtained with a diet of 'synthetic milk', namely I254 Cal.

The maintenance requirement of calves given whole milk, on the other hand, was considerably higher than of those given 'synthetic milk'. This was a general trend throughout all experiments and seems unlikely to have been due to experimental error. The percentage of total calories present as soluble carbohydrates in the synthetic

Table 4. Part 4. Whole-milk requirement for various live-zveight gains of calves of different birth weights, calculated by means of variable $Y_{2}$ (see p. 125)

\begin{tabular}{|c|c|c|c|c|c|}
\hline \multirow{2}{*}{$\begin{array}{l}\text { Live-weight } \\
\text { gain/day } \\
\text { (lb.) }\end{array}$} & \multirow[b]{2}{*}{ Exp. no. } & \multirow[b]{2}{*}{$\begin{array}{l}\text { No. of } \\
\text { calves }\end{array}$} & \multicolumn{3}{|c|}{ Milk requirement (pt./day) of calf of birth weight } \\
\hline & & & $60 \mathrm{lb}$. & $80 \mathrm{lb}$. & I $00 \mathrm{lb}$. \\
\hline \multirow[t]{9}{*}{$\circ$} & 6 & 20 & 3.57 & $4 \cdot 54$ & 552 \\
\hline & 7 & 24 & 3.76 & $4 \cdot 78$ & 5.80 \\
\hline & 8 & 34 & $3 \cdot 83$ & $4 \cdot 84$ & $5 \cdot 84$ \\
\hline & 9 & 21 & $3 \cdot 68$ & 4.88 & 6.02 \\
\hline & Io & 21 & $4^{\circ} 04$ & 5.08 & $6 \cdot 11$ \\
\hline & I I & 37 & $4 \cdot 18$ & $5 \cdot 14$ & 6.09 \\
\hline & 12 & 45 & $3 \cdot 48$ & $4 \cdot 62$ & 5.76 \\
\hline & Weighted mean & & $3.79(2 \cdot 151)$. & $4.84(2.751)$. & $5.88(3.341)$. \\
\hline & $\begin{array}{l}\text { Gross energy } \\
\text { (Cal.) }\end{array}$ & & I 508 & 1926 & 2340 \\
\hline \multirow[t]{8}{*}{0.5} & 6 & 20 & 5.00 & $5 \cdot 98$ & $6 \cdot 95$ \\
\hline & 7 & 24 & $5 \cdot 10$ & $6 \cdot 12$ & $7 \cdot 14$ \\
\hline & 8 & 34 & $5 \cdot 42$ & $6 \cdot 42$ & $7 \cdot 42$ \\
\hline & 9 & $2 \mathrm{I}$ & 5.08 & $6 \cdot 28$ & $7 \cdot 47$ \\
\hline & ro & $2 \mathrm{I}$ & 5.07 & $6 \cdot 11$ & $7 \cdot 14$ \\
\hline & II & 37 & $5 \cdot 42$ & $6 \cdot 38$ & $7 \cdot 33$ \\
\hline & r2 & 45 & $4 \cdot 80$ & $5 \cdot 94$ & 7.09 \\
\hline & $\begin{array}{l}\text { Weighted mean } \\
\text { Gross energy } \\
\text { (Cal.) }\end{array}$ & & $\begin{array}{l}5 \cdot 13(2 \cdot 921 .) \\
2042\end{array}$ & $\begin{array}{l}6 \cdot 18(3.5 \times 1 .) \\
2460\end{array}$ & $\begin{array}{l}7 \cdot 23(4 \cdot \text { I I l.) } \\
2878\end{array}$ \\
\hline \multirow[t]{8}{*}{$I \cdot O$} & 6 & 20 & $6 \cdot 44$ & $7 \cdot 42$ & $8 \cdot 39$ \\
\hline & 7 & 24 & $6 \cdot 44$ & $7 \cdot 46$ & $8 \cdot 48$ \\
\hline & 8 & 34 & $7 \cdot 00$ & 8.01 & $9^{\circ}$ O I \\
\hline & 9 & 21 & 6.48 & $7 \cdot 67$ & $8 \cdot 87$ \\
\hline & 10 & $2 \mathrm{I}$ & $6 \cdot 10$ & $7 \cdot 14$ & $8 \cdot 17$ \\
\hline & I I & 37 & $6 \cdot 66$ & $7 \cdot 62$ & $8 \cdot 57$ \\
\hline & 12 & 45 & $6 \cdot 13$ & 7.27 & $8 \cdot 41$ \\
\hline & $\begin{array}{l}\text { Weighted mean } \\
\text { Gross energy } \\
\text { (Cal.) }\end{array}$ & & $\begin{array}{l}6.47(3.681 .) \\
2575\end{array}$ & $\begin{array}{l}7 \cdot 52(4 \cdot 271 .) \\
2993\end{array}$ & $\begin{array}{l}8 \cdot 57(4 \cdot 871 .) \\
34 \text { I I }\end{array}$ \\
\hline
\end{tabular}

milk was much higher $(43.0 \%)$ than that in the whole milk $(26.2 \%)$. It is possible that glucose may be a more available source of energy than fat for the maintenance of the preruminant calf, for Armstrong, Blaxter \& Graham (1957) with fasting sheep have shown that the heat increment associated with the metabolism of steamvolatile fatty acids absorbed from the rumen is much higher than that of glucose. This difference in the maintenance requirement was not shown in treatment 5 of Exp. B, possibly because the calf can adjust its maintenance requirement by lowering its body temperature and reducing its basal metabolic rate. The significantly lower rectal temperature of calves given maintenance rations in both Exps. A 
and $\mathrm{B}$, with a tendency for increasing rectal temperature as the volume of milk given was increased, is of some interest.

Since Benedict \& Ritzman (I923) showed that steers on a maintenance ration had higher skin temperatures than those fasted or on a submaintenance ration, it has been known that the plane of nutrition can affect the body temperature of farm animals. The results obtained by us are in keeping with those of Robinson \& Lee (I947) who showed that lambs, hens and sows had higher rectal temperatures when given adequate food mixtures than when given 'maintenance' quantities only, a difference that was exaggerated at high environmental temperatures.

Table 5. Part 4. Comparison of the energy requirements for maintenance of the young calf obtained from multiple regression analyses with those obtained by other workers

This experiment, Part 4

Weight of calf (lb.)

Weight of calf $(\mathrm{kg})$

Metabolic body size*

Gross energy (Cal./24 h)

Metabolizable energy (Cal./24 h) †

Net energy (Cal./24 h) $\dagger$

Gross energy
Metabolizable energy $\dagger$

Netabolizable

\} (Cal. $/ \mathrm{kg} \mathrm{m}$

$\mathrm{f}(\mathrm{kg})$

Weight of calf $(\mathrm{kg})$

Apparent digestible energy (Cal./24 h)

$\begin{array}{llcc}60 & 80 & 100 & 130 \\ 27 \cdot 21 & 36 \cdot 29 & 45 \cdot 36 & 59 \cdot 27 \\ 11 \cdot 15 & 13 \cdot 76 & 16 \cdot 20 & 19 \cdot 69 \\ 1508 & 1926 & 2340 & 2964 \\ 1433 & 1830 & 2233 & 2816 \\ 1218 & 1556 & 1890 & 2394 \\ 135 & 140 & 144 & 151 \\ 129 & 133 & 137 & 143 \\ 109 & 113 & 117 & 122\end{array}$

Blaxter \& Wood (I95I $b$ )

Weight of calf $(\mathrm{kg})$

Metabolic body size (kg)*

Metabolizable energy

Net energy

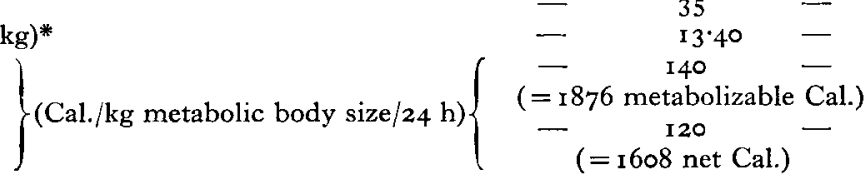

Tomme \& Taranenko (1939)

Weight of calf $(\mathrm{kg})$

Metabolic body size (kg)*

Net energy (Cal./24 h)

Net energy (Cal./kg metabolic body size/24 h)

$\begin{array}{llll}- & - & - & 59.27 \\ - & - & - & 19.69 \\ - & - & - & 2470 \\ & - & - & 125\end{array}$

* Metabolic body size $=W^{0.73}$, where $W=$ body-weight in kg (Brody, 1945).

$\uparrow$ Calculated from the factors of Blaxter (1952) (see text, below).

The difference between the adjusted mean live-weight gains for the calves in Exps. A and B expected to gain weight at 0.5 and $I \mathrm{lb}$./day can be accounted for by the difference in requirement for 'synthetic milk' and for whole milk, statistically calculated in Parts $\mathrm{I}$ and 4 and presented in Figs. $\mathrm{I}$ and 2.

For comparison with the findings of other workers, the net-energy value of whole milk for maintenance of body-weight was calculated by the use of the values found by Blaxter (1952), the gross energy being $95 \%$ metabolizable, of which $85 \%$ was available net energy. These calculated values are compared in Table 5 with the findings from the energy-balance experiments and respiration calorimetry of Blaxter \& Wood (195 I $b$ ), Blaxter (1952) and Tomme \& Taranenko (1939). 
It is clear that the net-energy values for maintenance obtained by multiple covariance analyses are very similar to those calculated from energy-balance experiments, although the former are slightly lower. Nevertheless a net-energy value of I 5 Cal. $/ \mathrm{kg}$ metabolic body size found by us for maintenance of a $90 \mathrm{lb}$. calf is in keeping with a mean basal metabolic rate of ro3 Cal. $/ \mathrm{kg}$ metabolic body size at I I days of age (Roy et al. I957).

\section{GENERAL DISCUSSION}

For experimental purposes, there is little doubt that the feeding standards reported by us should be used in preference to feeding at the rate of $\mathrm{I} \mathrm{lb}$. milk/ Io lb. live weight. By using the standards for whole milk given in Table 4, the experimental error should be reduced and the necessity of adjusting live-weight gain for both birth weight and milk consumption with resulting losses of degrees of freedom could be avoided. However, it is possible that a weight gain of $\mathrm{I} \mathrm{lb}$./day for the first 3 weeks of life for a small calf, i.e. $60 \mathrm{lb}$. in weight, cannot in fact be achieved in bucket-feeding regimes owing to the limiting factor of size of abomasum. Even so it would seem more logical for experimental purposes to feed a calf of this size so that its growth rate is as nearly as possible equal to that of a larger calf rather than to feed at the rate of I lb. milk/ro lb. live weight, which can but result in retarding the growth of the smaller calf.

In conclusion, it must be realized that these standards are average amounts of milk required by calves during the first 3 weeks of life for, as Roy et al. (1957) showed, the basal metabolic rate falls rapidly during the ist week of life and more slowly thereafter. The milk requirements will thus be somewhat higher during the first few days of life than at a later age. This higher requirement of energy during the early postnatal period is probably fully satisfied under practical conditions by colostrum feeding.

\section{SUMMARY}

I. Multiple covariance analyses on data for 232 Shorthorn and 92 Ayrshire bull calves have been made to determine the milk requirements for live-weight gain and for maintenance of body-weight of calves of various weights during the first 3 weeks of life.

2. Results for 122 Shorthorn calves were used to find the requirement for a 'synthetic milk', and the standards obtained were tested in a feeding trial with thirty-two Shorthorn calves. The trial indicated that the standards were correct.

3. The values obtained for the 'synthetic milk' were used in a second feeding trial with whole milk involving forty-eight Shorthorn calves. This trial indicated that the standards for the 'synthetic milk' were different from those for whole milk. Analysis of the data for 1 ro Shorthorn and 92 Ayrshire calves subsequently given whole milk indicated that the volume of whole milk for body-weight maintenance was greater, and that for live-weight gain slightly less, than that of the 'synthetic milk'.

4. The mean daily rectal temperatures of calves given a maintenance ration in the two feeding trials were significantly lower than those of calves given larger volumes of milk. 
5. The standards for quantities of whole milk to be given, obtained from the analyses, are presented and discussed in relation to the results of other workers. It is suggested that they should be used for experimental purposes in preference to feeding at the rate of $\mathrm{I} \mathrm{lb}$./ro lb. live weight.

\section{REFERENCES}

Andersen, A. C. (1926). Nord. FordbrForskn. p. 133 .

Armstrong, D. G., Blaxter, K. L. \& Graham, N. McC. (1957). Proc. Brit. Soc. Anim. Prod. p. 3.

Aschaffenburg, R., Bartlett, S., Kon, S. K., Roy, J. H. B., Walker, D. M., Briggs, C. \& Lovell, R. (I95 I). Brit. F. Nutr. 5, 171 .

Aschaffenburg, R., Bartlett, S., Kon, S. K., Terry, P., Thompson, S. Y., Walker, D. M., Briggs, C., Cotchin, E. \& Lovell, R. (1949). Brit. F. Nutr. 3, 187.

Benedict, F. G. \& Ritzman, E. G. (1923). Publ. Carneg. Instn, no. 324.

Blackwood, J. H., Morris, S. \& Wright, N. C. (1936). F. Dairy Res. 7, 228.

Blaxter, K. L. (1952). Brit. F. Nutr. 6, I2.

Blaxter, K. L. \& Wood, W. A. (195 I a). Brit. F. Nutr. 5, I I.

Blaxter, K. L. \& Wood, W. A. (195 I b). Brit. F. Nutr. 5, 55.

Blaxter, K. L. \& Wood, W. A. (1952a). Brit. F. Nutr. 6, I.

Blaxter, K. L. \& Wood, W. A. (1952b). Brit. F. Nutr. 6, 56.

Brody, S. (1945). Bioenergetics and Growth. New York: Reinhold Publishing Corp.

Brody, S., Kibler, H. H. \& Ragsdale, A. C. (1941). Res. Bull. Mo. agric. Exp. Sta. no. 335.

Brody, S., Kibler, H. H. \& Ragsdale, A. C. (1942). Res. Bull. Mo. agric. Exp. Sta. no. $35^{\circ}$.

Hunziker, O. F. (1949). Condensed Milk and Milk Powder, $7^{\text {th }}$ ed. Illinois: La Grange.

Ragsdale, A. C. (I934). Bull. Mo. agric. Exp. Sta. no. 336.

Robinson, K. W. \& Lee, D. H. K. (1947). F. Anim. Sci. 6, I82.

Roy, J. H. B., Huffman, C. F. \& Reineke, E. P. (1957). Brit. F. Nutr. Ix, 373.

Roy, J. H. B., Palmer, J. Shillam, K. W. G., Ingram, P. L. \& Wood, P. C. (1955). Brit. F. Nutr. 9, i I.

Roy, J. H. B., Shillam, K. W. G. \& Hawkins, G. M. (1956). Rep. Nat. Inst. Res. Dairy., Reading, p. 53.

Roy, J. H. B., Shillam, K. W. G., Palmer, J. \& Ingram, P. L. (1955). Brit. F. Nutr. 9, 94.

Tomme, M. F. \& 'Taranenko, G. A. (1939). Proc. Lenin Acad. agric. Sci. no. 10, p. 36.

Walker, D. M. (1950). Bull. Anim. Behav. 8, 5.

Woodman, H. E. (1948). Bull. Minist. Agric., Lond., no. 48. 